\title{
Corporate Social Responsibility And The Quality Of Executive Compensation Disclosures
}

\author{
Walid Ben-Amar, University of Ottawa, Canada \\ Nadia Smaili, University of Quebec at Montreal, Canada \\ Eustache Ebondo Wa Mandzila, Kedge Business School, France
}

\begin{abstract}
This paper examines the relationship between corporate social responsibility and executive compensation disclosure quality. We test whether socially responsible firms disclose more transparent and detailed information about their executive compensation packages than firms that are less committed to social responsibility initiatives. Using a sample of 187 publicly listed Canadian firms, we find a positive relation between CSR and executive compensation disclosure quality. We also document a positive (negative) association between firm size (ownership concentration) and executive compensation disclosure. These findings support the conclusion that increased disclosure transparency reflects a company's social engagement towards its stakeholders.
\end{abstract}

Keywords: Corporate Social Responsibility; Stakeholder Theory; Executive Compensation; Disclosure Quality

\section{INTRODUCTION}

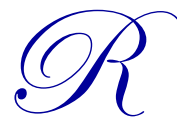

ecently, corporate social responsibility (CSR) has attracted increasing attention from shareholders, customers, regulators, and other firm's stakeholders. Many firms around the world are integrating, either voluntarily or under pressure from their stakeholders, social and environmental issues in their strategic planning (Deng et al., 2013). Stakeholder theory scholars argue that the firm should not only focus on shareholders' interests but should aim to serve all non shareholder stakeholders which should translate in better financial results (Freeman, 1984). However, the extent literature reports mixed evidence on the link between social and financial performance (McWilliams \& Siegel, 2000; Orlitzky et al., 2003; Barnett \& Solomon, 2012) and the causality direction between social performance and firm value remains an unresolved issue (Orlitzky et al., 2003; Cheng et al., 2013). In an attempt to further explain the causality link between CSR investments and financial performance, recent academic research has explored the channels through which the adoption of socially responsible practices may affect financial performance. Recent studies have examined executive compensation practices (Frye et al., 2006; Cai et al., 2011; Collett Miles \& Miles, 2013), financial reporting quality and disclosure practices (Gelb \& Strawser, 2001; Kim et al., 2012; Dawkins \& Fraas, 2013), and corporate investment strategies (Deng et al., 2013) of socially responsible (SR) firms.

The objective of this paper is to examine the relationship between the adoption of social responsibility practices and the quality of executive compensation disclosure. Gelb \& Strawser (2001) contend that managers may use their voluntary disclosure practices as a device to show their commitment to high ethical standards that promote disclosure transparency. Therefore, stakeholders may expect that socially responsible firms will exhibit higher transparency in their financial and non financial disclosures than other firms because transparent disclosures reflect a socially responsible behavior (Gelb \& Strawser, 2001). Following this argument, we test whether SR firms disclose more transparent and detailed information about their executive compensation packages than firms that are less engaged in social responsible initiatives. We focus on executive compensation disclosures because investors, regulators, and other stakeholders in many countries around the world have raised a number of concerns over 
excessive compensation packages granted to executives as well as the lack of transparency of executive compensation disclosures (Core et al., 2003; McFarland, 2003; Schiehll, 2005). ${ }^{1}$

Based on a sample of 187 firms listed on Toronto Stock Exchange, we find a positive and significant relationship between the adoption of social responsibility practices and transparency of executive compensation disclosure. These results are consistent with Gelb \& Strawser (2001) and suggest that increased disclosure transparency reflects firm's social engagement towards its stakeholders. Our paper contributes to the growing literature on financial disclosure and reporting practices of socially responsible firms (Chih et al., 2008; Kim et al., 2012; Dawkins \& Fraas, 2013; Hoi et al., 2013). It also extends the findings of prior studies on the determinants of compensation disclosure quality (Coulton et al., 2001; Clarkson et al., 2006; Laksmana, 2008; Muslu, 2010; BenAmar \& Zeghal, 2011) by showing that the firm's commitment towards its stakeholders is a key determinant of its disclosure policy. To the best of our knowledge, this paper is the first to examine this association between social responsibility and the transparency of executive compensation disclosure.

The rest of the paper is organized as follows. In the next section, we review relevant literature and present our research hypothesis. In the third section, we describe our sample and research methodology. The fourth section presents and discusses the study's results and is followed by a conclusion.

\section{RELATED LITERATURE AND HYPOTHESIS}

Stakeholder theory suggests that the firm should serve the interests of all its stakeholders (Freeman, 1984). Therefore, in addition to shareholders' wealth, socially responsible firms should care about the welfare of their employees, customers, local communities in which they operate, and other non shareholder stakeholders (Frye et al., 2006). CSR investments should translate in better financial results through a better access of the firm to valuables resources such as quality employees, better marketing of the firm's products and social legitimacy with local communities (Cheng et al., 2013). However, empirical studies that explored the link between social and financial performance provide mixed evidence (Orlitzky et al., 2003; Barnett \& Solomon, 2012; Cheng et al., 2013).

To better understand the link between stakeholder management and financial performance, recent academic research has explored whether compensation practices, financial reporting, and disclosure strategies and growth strategies differ between socially and non socially responsible. Frye et al. (2006) document a weaker payperformance link and a higher probability of CEO turnover in SR firms in comparison to non SR firms. Cai et al. (2011) and Collett Miles \& Miles (2013) report a negative association between the adoption of socially responsible practices and CEO compensation levels. Cai et al. (2011) argue that their findings are consistent with the conflictresolution hypothesis of CSR. CEO in SR firms with high ethical standards may accept a lower compensation than CEO in non SR firms to help alleviate potential agency conflicts with other stakeholders and avoid any concerns about wealth distribution between the firm and its stakeholders (Cai et al., 2011). Previous research shows also that firm's social performance affects the financial success of major investments. Consistent with the stakeholder value maximization, Deng et al. (2013) find that mergers undertaken by SR firms generate higher returns to their shareholders and are associated to better long term operating performance than mergers by non SR firms. Given the stakeholders' support, Deng et al. (2013) show also that mergers by SR firms are finalized quicker and are less likely to fail than mergers undertaken by non SR firms.

Previous research (Gelb \& Strawser, 2001; Chih et al., 2008; Kim et al. 2012) suggest also that social performance may be related to financial reporting quality as well as financial disclosure practices. This literature is based on ethical theories (Carroll, 1979; Jones, 1995; Donaldson \& Preston, 1995) which suggest that the firm has an 'ethical obligation' towards its stakeholders. Kim et al. (2012, p. 765) contend that SR 'firms/managers have an incentive to be honest, trustworthy and ethical in their business processes, and thus tend to adhere to a high standard of behavior.' Therefore, stakeholders may expect that accounting choices and disclosure practices of SR firms will reflect the managers' and company's high ethical values. Consistent with this ethical obligation, Kim et al. (2012) find that SR firms are less likely to manage earnings either through discretionary accruals or real

\footnotetext{
${ }^{1}$ Regulatory authorities in The United States and Canada have enacted in 2006 and 2008 new rules and regulations to enhance the transparency of the information disclosed about executive compensation practices and respond to stakeholders' concerns.
} 
operating activities than non SR firms. Their results show also that SR firms are less likely to be involved in SEC investigations. Chih et al. (2008) report also a negative association between CSR and earnings smoothing in a large sample of firms from 46 countries. Consistent with the ethical commitment of SR firms, Hoi et al. (2013) document a negative association between social responsibility initiatives and tax avoidance activities.

Gelb \& Strawser (2001) conjecture that the firm's disclosure practices will reflect its commitment towards its stakeholders. Based on the firm's ethical obligation, Gelb \& Strawser (p. 3) contend that 'increased disclosure is a form of social responsible behavior.' Their results show that SR firms are associated to more extensive financial disclosure than non SR firms. Dawkins \& Fraas (2013) document also that social performance affects disclosure practices in the annual report. Following Gelb \& Strawser (2001), we expect that SR firms will exhibit more transparency in their executive compensation disclosures than non SR firms. Given the stakeholders' concerns about executive compensation levels and lack of transparency of information about compensation practices, we expect that SR will respond to these concerns by enhancing their disclosure transparency. Managers of SR firms will adhere to high ethical values and are more likely to integrate stakeholders' demands for increased disclosures about compensation practices. We therefore expect a positive association between the adoption of social responsibility practices and executive compensation disclosure transparency. We offer an empirical test of the following hypothesis H1:

H1: Socially responsible firms disclose more transparent information about their executive compensation practices than non-socially responsible firms.

\section{METHODOLOGY}

\subsection{Sample Description}

This paper explores the link between social performance and compensation disclosure transparency of a sample of Canadian firms listed on the Toronto Stock Exchange. We focus on firms included in the S\&P TSX composite index with available corporate governance rankings in The Globe \& Mail (G\&M) Report on Business (ROB) annual study of corporate governance practices. The Globe \& Mail has published annual scores of the corporate governance practices of Canadian publicly listed firms since 2002. The G\&M annual survey assesses the quality of board composition, shareholding and compensation policy, shareholder rights policy, and corporate governance disclosure quality (McFarland, 2006). Previous studies relied on the G\&M corporate governance scores to examine the relationship between corporate governance quality and firm value (Klein et al., 2005) and earnings quality (Niu, 2006). We focus on the year 2006 because the G\&M introduced in that year an important change to the annual governance index with the addition of several questions designed to assess the transparency of compensation disclosure (McFarland, 2006). We use the G\&M compensation disclosure scores to evaluate the transparency of information disclosed about executive compensation practices. Further, we limit our analysis to the year 2006 because new executive compensation disclosure rules were introduced in Canada in 2008. The new disclosure rules introduced a standardized format for the presentation of compensation related information and thus limited the discretion that managers enjoyed previously in the disclosure of compensation practices. Our final sample includes 187 firms with available disclosure scores, financial, ownership, and compensation data.

\subsection{Variable Description}

Table 1 presents a description of the study's variables. Our dependent variable is the executive compensation disclosure transparency. Similar to Ben-Amar \& Zeghal (2011) we rely on the G\&M 2006 compensation disclosure scores to measure our dependent variable. The G\&M has evaluated the disclosure practices related to the information provided about the CEO total compensation, the quality of disclosures in relation to the CEO bonus, disclosure about the annual pension paid to the CEO upon retirement as well as disclosures on the value of the CEO's equity ownership (McFarland, 2006). This variable ranges from 0 to 10 . Table 2 presents the distribution of 10 marks between the disclosure items. 
Table 1: Variable Description

\begin{tabular}{|c|c|c|}
\hline Variable & Expected Sign & Description \\
\hline \multicolumn{3}{|l|}{ Dependent Variable } \\
\hline Disclosure Score & & $\begin{array}{l}\text { Executive Compensation Disclosure Transparency score as reported in } \\
\text { the } 2006 \text { G\&M annual corporate governance rankings. This variable } \\
\text { ranges from } 0 \text { to } 10 \text { (Source: The Globe } \& \text { Mail). }\end{array}$ \\
\hline \multicolumn{3}{|l|}{ Independent Variable } \\
\hline Social Responsibility & + & $\begin{array}{l}\text { Dummy variable that equals one if the company is included in the Jantzi } \\
\text { Social Index as of } 31 \text { December } 2005 \text { and zero otherwise } \\
\text { (Sustainalytics.com). }\end{array}$ \\
\hline \multicolumn{3}{|l|}{ Control Variables } \\
\hline Ownership Concentration & & $\begin{array}{l}\text { Dummy variable that equals one if inside ownership exceeds } 10 \% \text { and } \\
\text { zero otherwise (Source: Stock-Guide Database). }\end{array}$ \\
\hline Options Percentage & - & $\begin{array}{l}\text { Ratio of Options compensation to the CEO total compensation } \\
\text { (Source: proxy circulars) }\end{array}$ \\
\hline Firm Size & + & Logarithm of total assets (Source: Stock-Guide Database) \\
\hline Leverage & $+/-$ & $\begin{array}{l}\text { Leverage ratio (total debt / total assets) } \\
\text { (Source: Stock-Guide Database). }\end{array}$ \\
\hline ROA $(\%)$ & $+/-$ & Return on Assets (Source: Stock-Guide Database). \\
\hline Pricetobook & + & $\begin{array}{l}\text { Ratio of the market value to the book value of equity } \\
\text { (Source: Stock-Guide Database). }\end{array}$ \\
\hline
\end{tabular}

Table 2: Distribution of Executive Compensation Disclosure Marks

\begin{tabular}{|l|c|}
\hline \multicolumn{1}{|c|}{ Disclosure Item } & Maximum Marks \\
\hline CEO bonus & 4 \\
\hline CEO total compensation & 2 \\
\hline CEO estimated annual pension & 1 \\
\hline Accrued pension liability for the CEO & 1 \\
\hline Total value of the CEO's accumulated shares, DSUs or other equity holdings & 1 \\
\hline $\begin{array}{l}\text { Total cost of compensation to the top executive team as a percentage of the total profit or } \\
\text { total shareholder return for the year }\end{array}$ & 1 \\
\hline Total & $\mathbf{1 0 ~ m a r k s}$ \\
\hline
\end{tabular}

Our independent variable, corporate social responsibility, is a dummy variable that takes the value of one if the company is included in the Jantzi Social Index as of 31 December 2005 and zero otherwise. The Jantzi social index was launched in 2000 by Jantzi research ${ }^{2}$ and consists of 60 Canadian companies rated based on environmental, social and governance criteria. The Jantzi social index does not include firms operating in 'irresponsible' activities such as the manufacturing of tobacco products, fire arms industry, and nuclear power production. Prior studies used similar approaches to assess corporate social performance. For instance, Frye et al. (2006) used the 400 firms included in Domini Social (DS 400) index as a sample of socially responsible firms. Chih et al. (2008) consider that firms included in the FTSE4 GOOD index as socially responsible.

Consistent with executive compensation disclosure literature (Clarkson et al., 2006; Laksmana, 2008; Muslu, 2010), we control for several control variables deemed to affect the firm's disclosure practices. The control variables include ownership concentration, percentage of stock options in total compensation, firm size, leverage, firm performance, and growth opportunities. Ownership concentration reduces agency costs as well as the need for extensive disclosures to reduce information asymmetry. Laksmana (2008, p. 1161) argue also 'that the presence of blockholders and institutional holders could reduce the concerns of outside shareholders about unjustified executive compensation.' This suggests a negative association between ownership concentration and executive compensation disclosure quality. Consistent with Laksmana (2008), we expect also a negative relation between stock options compensation's percentage in CEO total compensation. Previous studies suggest that the level of disclosure is related to the firm's financial characteristics. For example, Meek et al. (1995), Eng \& Mak (2003) and Lang \& Lundholm (1993) find a positive association between firm size and disclosure levels. In addition, Ahmed \& Courtis (1999) show that leverage is associated with the level of disclosure. We also control for firm performance in our

${ }^{2}$ In 2009, Jantzi Research merged with Sustainalytics (www.sustainalytics.com). 
multivariate analysis because a number of previous studies (Ahmed \& Courtis, 1999; Lang \& Lundholm, 1993) report a significant relation between firm performance and disclosure quality. We measure firm performance by the return on assets (ROA). Finally, we expect a positive association between growth opportunities and the transparency of executive compensation disclosure (Hossain et al., 2005). We measure the growth opportunities by the ratio of the market value to the book value of equity.

\section{RESULTS}

\subsection{Descriptive Statistics}

Table 3 presents the main descriptive statistics of our variables. Our sample includes 187 firms, 49 socially responsible firms included in Jantzi social index and 138 non-socially responsible firms. The average disclosure score is 3.39 while the median is 3.00 . Given that the disclosure score varies between 0 and 10 , the average and median scores suggest that information disclosed about executive compensation packages of our sample firms is rather poor. Table 3 shows that socially responsible firms exhibit higher executive compensation disclosure scores than non-socially responsible counterparts. The average executive compensation disclosure score is 4.67 for socially responsible sample in comparison to 2.93 for non-socially responsible firms. The difference between the two groups is statistically significant. With regards to control variables, Table 3 shows that socially responsible firms are larger and are associated with lower growth opportunities than non-socially responsible firms.

Table 3: Descriptive Statistics

\begin{tabular}{|l|c|c|c|c|c|c|c|c|c|c|c|}
\hline & \multicolumn{3}{|c}{$\begin{array}{c}\text { Total Sample } \\
\text { (N = 187) }\end{array}$} & \multicolumn{2}{c|}{$\begin{array}{c}\text { Socially Responsible Firms } \\
\text { (N= 49) }\end{array}$} & \multicolumn{3}{c|}{$\begin{array}{c}\text { Non-Socially } \\
\text { Responsible Firms } \\
\text { (N = 138) }\end{array}$} & Stat. t \\
\hline & Mean & Median & SD & Mean & Median & SD & Mean & Median & SD & \\
\hline
\end{tabular}

Table 4 presents the matrix correlations between variables. These preliminary results show that executive compensation disclosure score is positively correlated to social responsibility dummy and size firm and negatively correlated to ownership concentration. The relatively low correlation coefficients between our explanatory variables suggest that multicollinearity is not a serious threat to our multivariate analysis.

Table 4: Correlations Matrix

\begin{tabular}{|c|c|c|c|c|c|c|c|c|}
\hline & $\begin{array}{l}\text { Disclosure } \\
\text { Score }\end{array}$ & $\begin{array}{c}\text { Social } \\
\text { Responsibility }\end{array}$ & $\begin{array}{c}\text { Ownership } \\
\text { Concentration }\end{array}$ & $\begin{array}{c}\text { Options } \\
\text { Percentage }\end{array}$ & Size & Leverage & ROA & $\begin{array}{c}\text { Price to } \\
\text { Book }\end{array}$ \\
\hline $\begin{array}{l}\text { Disclosure } \\
\text { Score }\end{array}$ & 1 & & & & & & & \\
\hline $\begin{array}{l}\text { Social } \\
\text { Responsibility }\end{array}$ & $0.34 * * *$ & 1 & & & & & & \\
\hline $\begin{array}{l}\text { Ownership } \\
\text { Concentration }\end{array}$ & $-0.19 * *$ & -0.09 & 1 & & & & & \\
\hline $\begin{array}{l}\text { Options } \\
\text { Percentage }\end{array}$ & 0.02 & -0.06 & -0.02 & 1 & & & & \\
\hline Size & $0.34 * * *$ & $0.46 * * *$ & -0.10 & -0.03 & 1 & & & \\
\hline Leverage & -0.06 & 0.11 & $0.15 * *$ & 0.03 & $0.22 * * *$ & 1 & & \\
\hline ROA & 0.04 & 0.02 & 0.09 & -0.08 & $0.17 * *$ & 0.10 & 1 & \\
\hline Price-to-Book & -0.01 & $-0.12 *$ & -0.05 & 0.00 & $\begin{array}{c}-0.34 \\
* * *\end{array}$ & $-0.19 * *$ & $-0.18 * *$ & 1 \\
\hline
\end{tabular}




\subsection{Multivariate Analysis}

Table 5 presents the results of an ordered regression of compensation disclosure transparency on social responsibility score and control variables. Our dependent variable is an ordinal variable that takes values between 0 and 10, we therefore rely on an ordered probit model to estimate our regression. Our results show a positive and significant association between corporate social responsibility and executive compensation disclosure quality (coefficient: 0.637 ; t-stat: 2.99 ). This finding supports our hypothesis that socially responsible firms disclose more transparent and detailed information about their compensation practices. These results agree with previous studies (Gelb \& Strawser, 2001; Dawkins \& Fraas, 2013) which report a positive association between social performance and financial disclosures levels. These findings support the conclusion that increased disclosure transparency reflects a company's social engagement towards its stakeholders.

Consistent with previous studies, we document a positive association between firm size and executive compensation disclosure transparency (coefficient: 0,132; t-stat: 2). Our results agree with Lang \& Lundholm (1993) and Ahmed \& Courtis (1999) and suggest that large firms have more resources and expertise to prepare and disclose more detailed and transparent information about their executive compensation practices. As shown, in Table 5, we document a negative association between ownership concentration and executive compensation disclosure quality. This finding agrees with agency theory predictions which suggest that ownership concentration reduce agency costs and incentives for additional disclosures. Our results are also consistent with Laksmana's (2008) suggestion that ownership concentration (presence of blockholders) may reduce the concerns of outside shareholders about excessive executive compensation as well as the need for extensive disclosures about the details of compensation packages awarded to executives. Finally, according to results in Table 5 there is no significant association between compensation disclosure score and firm performance, leverage, growth opportunities or the proportion of option compensation.

Table 5: Social Responsibility and Executive Compensation Disclosure Transparency

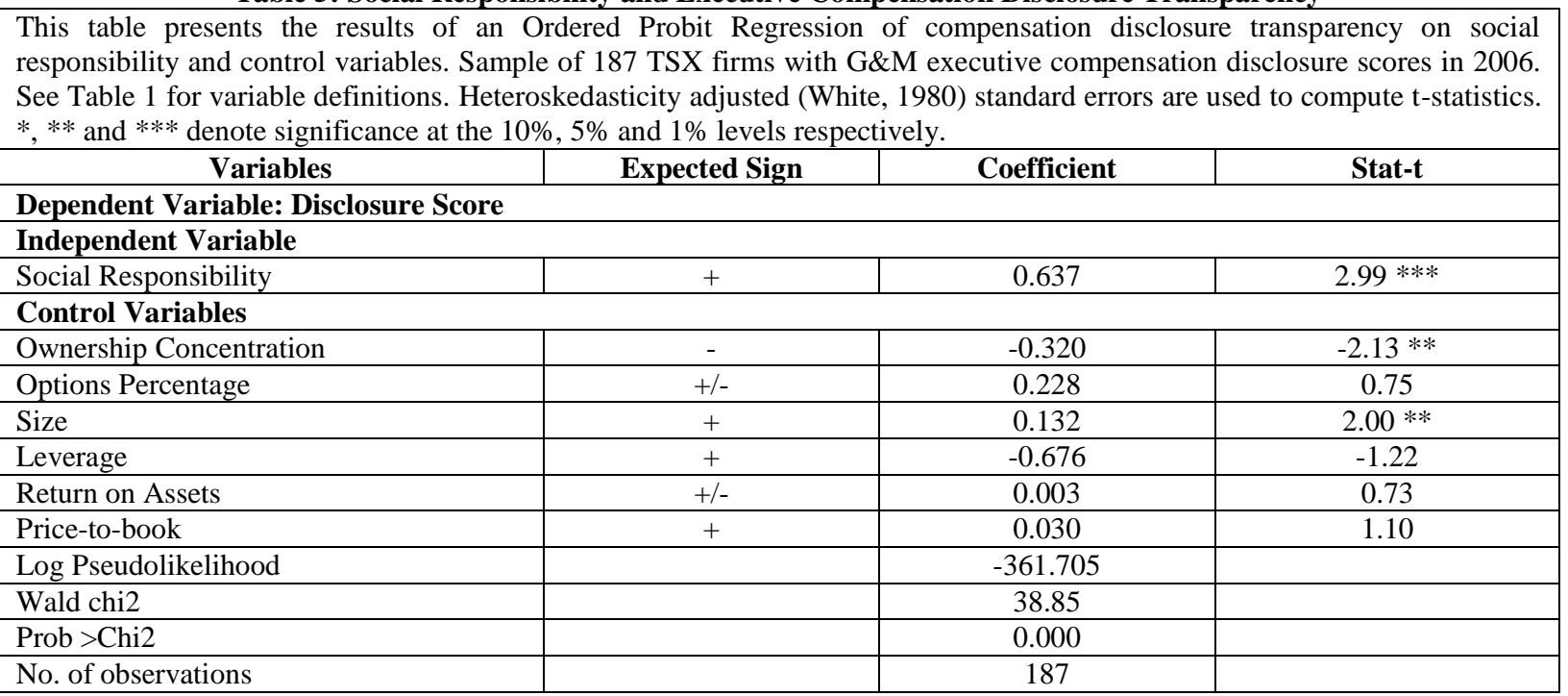

\section{CONCLUSION}

This paper investigates the association between social responsibility and executive compensation disclosure quality for a sample of 187 firms listed on the Toronto Stock Exchange. Following Gelb \& Strawser (2001), we argue that stakeholders may expect that SR firms will exhibit higher transparency in their financial and non financial disclosures than other firms because transparent disclosures reflect a socially responsible behavior (Gelb \& Strawser, 2001). We therefore test whether socially responsible firms disclose more transparent and detailed information about their executive compensation packages than non-socially responsible firms. Consistent with our expectation, we find a positive association between social responsibility and the transparency of executive 
compensation disclosures. This finding suggests that stakeholders can play a key role in improving the transparency of the information disclosed about compensation practices and thus may limit managers' rent extraction trough excessive compensation. Our results contribute to the growing literature on financial reporting quality and disclosure practices of SR firms (Gelb \& Strawser, 2001; Chih et al., 2008 Kim et al., 2012; Dawkins \& Fraas, 2013).

\section{AUTHOR INFORMATION}

Walid Ben-Amar is an associate professor of accounting at the Telfer School of Management of the University of Ottawa in Canada. He holds a Ph.D. in accounting from HEC Montreal. He has published papers in the areas of corporate governance, family firms, mergers, and acquisitions and disclosure strategies. E-mail: benamar@telfer.uottawa.ca (Corresponding author)

Nadia Smaili is a professor of accounting at the University of Quebec at Montreal in Canada. She holds a Ph.D in accounting from HEC Montreal. Her main research interests include corporate fraud, corporate governance, and disclosure policy. Her work has been published in refereed journals in accounting and corporate law. E-mail: smaili.nadia@uqam.ca

Eustache Ebondo Wa Mandzila, Ph.D., is an associate professor of auditing and corporate governance at Kedge Business School, Marseille, France. His research interests include corporate governance, internal controls, and audit quality. His work has been published in several French academic journals. He also authored numerous books on auditing and corporate governance. E-mail: eustache.ebondo@kedgebs.com

\section{ACKNOWLEDGEMENTS}

Walid Ben-Amar gratefully acknowledges the financial support from the CGA-Canada Accounting and Governance Research Centre and from the Telfer School of Management Research fund.

\section{REFERENCES}

1. Ahmed, K., \& Courtis J. (1999). Association between corporate characteristics and disclosure levels in annual reports: a meta-analysis. British Accounting Review, 31, 35-61.

2. Barnett, M., \& Salomon, R. M. (2012) Does it pay to be really good? Addressing the shape of the relationship between social and financial performance. Strategic Management Journal, 33(11), 1304-1320.

3. Ben Amar, W., \& Zéghal, D. (2011). Board of directors' independence and executive compensation disclosure transparency: Canadian evidence. Journal of Applied Accounting Research, 12(1), 43-60.

4. Cai, Y., Jo, H., \& Pan, C. (2011). Vice or virtue? The impact of corporate social responsibility on executive compensation. Journal of Business Ethics, 104, 1159-173.

5. Carroll, A. (1979). A three-dimensional conceptual model of corporate performance. The Academy of Management Review, 4(4), 497-505.

6. Chen, B., Ioannou, I., \& Serafeim, G. (2013). Corporate social responsibility and access to finance. Strategic Management Journal. Forthcoming.

7. Chih, J. L., Shen, C. H., \& Kang. F. C. (2008). Corporate social responsibility, investor protection, and earnings management: Some international evidence. Journal of Business Ethics, 79, 179-198.

8. Clarkson, P., Van Bueren, A. L., \& Walker, J. (2006). Chief executive officer remuneration disclosure quality: Corporate reponses to an evolving disclosure environment. Accounting and Finance, 46, 771-796.

9. Collett Miles, P., \& Miles G. (2013). Corporate social responsibility and executive compensation: Exploring the link. Social Responsibility Journal, 9(1), 76-90.

10. Core, J., Guay, W., \& Larcker, D. (2003). Executive equity compensation and incentives: A survey. Federal Reserve Bank of New York Economic Policy Review, April, 27-50.

11. Coulton. J., James, C., \& Taylor, S. (2001). The effect of compensation design and corporate governance on the transparency of CEO compensation disclosures. (Working Paper). Sydney, Australia: University of Technology.

12. Dawkins, C., \& Fraas, J. W. (2013). An exploratory analysis of corporate social performance and disclosure. Business \& Society, 52, 245-281. 
13. Deng, X., Kang, J. K., \& Low, B. S. (2013). Corporate social responsibility and stakeholder value maximization: Evidence from mergers. Journal of Financial Economics, 110, 87-109.

14. Donaldson, T., \& Preston, L. (1995). The stakeholder theory of the corporation: Concepts, evidence and implications. The Academy of Management Review, $20(1), 65-91$.

15. Eng, L., \& Mak, Y. (2003). Corporate governance and voluntary disclosure. Journal of Accounting and Public Policy, 22, 325-345.

16. Freeman, R. E. (1984). Strategic management: A stakeholder perspective. Boston, MA: Pitman.

17. Frye, M. B., Nelling, E., \& Webb, E. (2006). Executive compensation in socially responsible firms. Corporate Governance: An International Review, 14(5), 446-455.

18. Gelb, D. S., \& Strawser, J. A. (2001). Corporate social responsibility and financial disclosure: An alternative explanation for increased disclosure. Journal of Business Ethics, 33, 1-13.

19. Hossain, M., Ahmed, K., \& Godfrey, J. M. (2005). Investment opportunity set and voluntary disclosure of prospective information: A simultaneous equations approach. Journal of Business Finance \& Accounting, 32(5 \& 6), 877-907.

20. Hoi, C. K., Wu, Q., \& Zhang, H. (2013). Is corporate social responsibility (CSR) associated with tax avoidance? Evidence from irresponsible CSR activities. The Accounting Review, 88(6), 2025-2059.

21. Jones, T. (1995). Instrumental stakeholder theory: A synthesis of ethics and economics. The Academy of Management Review, 20(2), 404-437.

22. Klein, P., Shapiro, D., \& Young, J. (2005). Corporate governance, family ownership and firm value. Corporate Governance: An International Review, 13(6), 760-784.

23. Kim, Y., Park, M. S., \& Wier, B. (2012). Is earnings quality associated with corporate social responsibility? The Accounting Review, 87(3), 761-796.

24. Laksmana, I. (2008). Corporate board governance and voluntary disclosure of executive compensation practices. Contemporary Accounting Research, 25, 1147-1182.

25. Lang, M., \& Lundholm, R. (1993). Cross-sectional determinants of analysts' ratings of corporate disclosures. Journal of Accounting Research, 31, 246-271.

26. McFarland, J. (2006). Board games methodology-corporations. The Globe and Mail, 25 October 2006. Available from http://v1.theglobeandmail.com/v5/content/boardgames2006/methodology-corporations.html

27. McFarland, J. (2003), Firms break pay disclosure rules. The Globe and Mail, 23 September 2003.

28. McWilliams, A. \& Siegel, D. (2000). Corporate social responsibility and financial performance: Correlation or misspecification? Strategic Management Journal, 21(5), 603-609.

29. Meek, G. K., Roberts, C. B., \& Gray, S. (1995). Factors influencing voluntary annual report disclosures by US, UK and continental European multinational corporations. Journal of International Business Studies, 26(3), 555-572.

30. Muslu, V. (2010). Executive directors, pay disclosures and incentive compensation in large European companies. Journal of Accounting Auditing and Finance, 25, 569-605.

31. Niu, F. F. (2006). Corporate governance and the quality of accounting earnings: A Canadian perspective. International Journal of Managerial Finance, 2(4), 302-327.

32. Orlitzky, M., Schmidt, F. L., \& Rynes, S. L. (2003). Corporate social and financial performance: A metaanalysis. Organization Studies, 24(3), 403-441.

33. Schiehll, E. (2005). Executive compensation disclosure: are Canadian companies doing it right? CMA Management, June/July. Retrieved 15 November 2013 from http://www.cmacanada.org/index.cfm/ci_id/2085/la_id/1

34. White, H. (1980). A heteroskedasticity-consistent covariance matrix estimator and a direct test for heteroskedasticity. Econometrica, 48, 817-38. 